\title{
Author Correction: Reproducibility of animal research in light of biological variation
}

Bernhard VoelkI(D), Naomi S. Altman (D), Anders Forsman (iD, Wolfgang Forstmeier(D), Jessica Gurevitch (D), Ivana Jaric (D), Natasha A. Karp (D), Martien J. Kas (D), Holger Schielzeth (D), Tom Van de Casteele (D) and Hanno Würbel(D)

Nature Reviews Neuroscience (2020) https://doi.org/10.1038/s41583-020-0313-3 Published online 2 June 2020

The originally published article contained an error in the references. The following paper was incorrectly included as REF. 47: Gur, E. et al. The variability of organ weight background data in rats. Omics 27, 65-72 (1999). The paper that should have been included as REF. 47 is: Åhlgren, J. \& Voikar, V. Housing mice in the individually ventilated or open cages - does it matter for behavioral phenotype? Genes Brain Behav. 18, e12564 (2019). This has been corrected in the HTML and PDF versions of the manuscript.

https://doi.org/10.1038/s41583-020-0326-y I Published online 8 June 2020

(c) Springer Nature Limited 2020 